\title{
Shopping Cart Abandonment among Young Adult in Malaysia: Exploring the Drivers of Cart Abandonment and Consumer Behaviour's
}

Salina Mad, Nor Alwani Omar, Ezzah Suraya Sarudin

To Link this Article: http://dx.doi.org/10.6007/IJARBSS/v11-i10/11171 DOI:10.6007/IJARBSS/v11-i10/11171

Received: 10 August 2021, Revised: 08 September 2021, Accepted: 28 September 2021

Published Online: 28 October 2021

In-Text Citation: (Mad et al., 2021)

To Cite this Article: Mad, S., Omar, N. A., \& Sarudin, E. S. (2021). Shopping Cart Abandonment among Young Adult in Malaysia: Exploring the Drivers of Cart Abandonment and Consumer Behaviour's. International Journal of Academic Research in Business and Social Sciences, 11(10), 949-961.

Copyright: @ 2021 The Author(s)

Published by Human Resource Management Academic Research Society (www.hrmars.com)

This article is published under the Creative Commons Attribution (CC BY 4.0) license. Anyone may reproduce, distribute, translate and create derivative works of this article (for both commercial and non-commercial purposes), subject to full attribution to the original publication and authors. The full terms of this license may be seen at: http://creativecommons.org/licences/by/4.0/legalcode

Vol. 11, No. 10, 2021, Pg. $949-961$

Full Terms \& Conditions of access and use can be found at http://hrmars.com/index.php/pages/detail/publication-ethics 


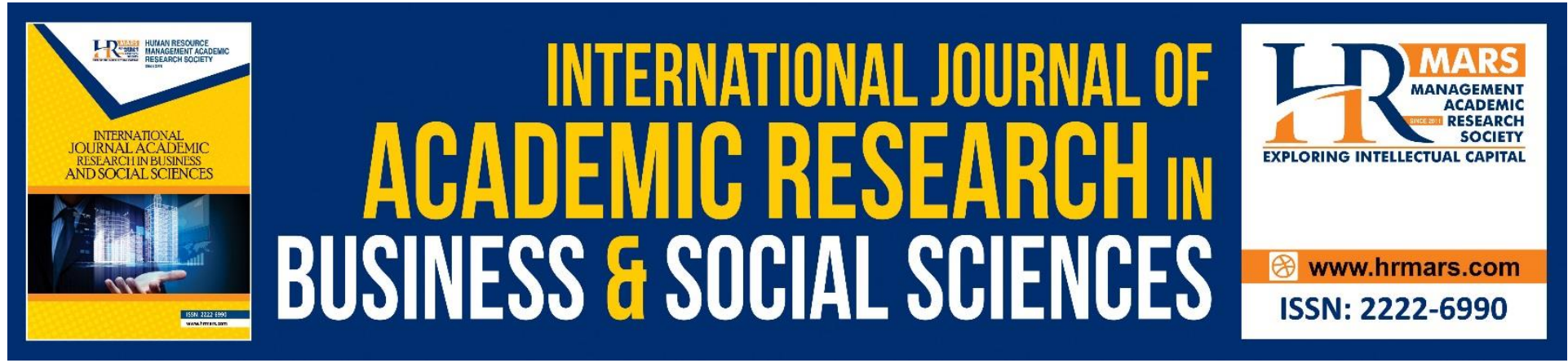

\title{
Shopping Cart Abandonment among Young Adult in Malaysia: Exploring the Drivers of Cart Abandonment and Consumer Behaviour's
}

\author{
Salina Mad \\ Faculty of Accountancy, Universiti Teknologi MARA, Perak Branch, Tapah Campus, 35400 \\ Tapah Road, Perak, MALAYSIA \\ Email: salina2439@uitm.edu.my
}

Nor Alwani Omar

Faculty of Computer and Mathematical Sciences, Universiti Teknologi MARA, Perak Branch, Tapah Campus, 35400 Tapah Road, Perak, MALAYSIA

Email: noralwani@uitm.edu.my

\begin{abstract}
Ezzah Suraya Sarudin
Faculty of Computer and Mathematical Sciences, Universiti Teknologi MARA, Perak Branch, Tapah Campus, 35400 Tapah Road, Perak, MALAYSIA

Email: ezzahsuraya@uitm.edu.my
\end{abstract}

\begin{abstract}
Online shopping has been around for decades; however, only recently it becomes mainstream, especially during a pandemic. Due to the rise of online shopping activities, the rate of shopping cart abandonment also increases concurrently. This issue damages the etailer's business. It causes trillions of dollar losses annually and generates problems such as high advertising costs, signals a poor user experience and impacts website analytics. Thus, this research is conducted to delve into this topic and explain this behaviour among young adults. A self-administered online questionnaire has been conducted and distributed to people in their 20's to '30s, and 255 completed questionnaires were obtained. However, only 252 respondents were analyzed. Regression and correlation analysis documented that organizational tools, entertainment value, and perceived cost were the underlying factors leading to young adults' shopping carts abandonment. These findings will help the e-tailers to understand young adult behaviour towards online shopping and can be treated as indications to lessen shopping cart abandonment.
\end{abstract}

Keywords: Cart Abandonment, Malaysia, Covid-19, e-tailer, Online Shopping

\section{Introduction}

E-commerce refers to buying and selling activities that are conducted via a computer network. Developing countries such as Malaysia, Singapore, Thailand and Pakistan have recorded an 
increased in the number of buyers in e-commerce (Bhatti et al., 2020). A survey conducted by the Malaysian Communications and Multimedia Commission (MCMC) for the year 2020 revealed $88.7 \%$ of the Malaysian population are Internet users which $64.2 \%$ of them use the Internet for online shopping compared to only 53.3\% in 2018 (Internet User Survey, 2020). The increase in online shopping activities is induced by Covid-19 and movement control order (MCO).

Due to pandemic and MCO, people avoiding or are restricted to go out; thus, they opt to conduct more buying activities online as a new norm. Department of Statistics (2020) reported income for e-commerce in Malaysia for 2020 has increased by $32.7 \%$ compared to 2019, with total revenue of RM 896.4 billion. Meanwhile, RM 254.6 billion e-commerce income was recorded in the first quarter of 2021, increasing $30 \%$ compared to the same period in the previous year. Besides, $80 \%$ of respondents reported POS Malaysia (one of the logistic companies in Malaysia) received a double number of parcels than usual during MCO (Kee et al. 2021). These proved that online shopping had become a part of an essential activity during a pandemic and further led to the growth of e-commerce in Malaysia.

Unfortunately, as the online shopping sales rose, shopping cart abandonment climbed as well. Shopping cart abandonment refers to when a potential customer adds an item to the cart but leave the portal without completing the purchase or leave it in the shopping cart (Gurley, 2000; Lee and Lee, 2004; Coppola and Sousa, 2008; Manjula and Kumar, 2019). STATISTA (2021) reported global shopping cart abandonment rate as of 2020 is $85.2 \%$; 8 out 10 customers will abandon items in their shopping cart. During the observed period, the highest rate is from the Middle East and Africa region (90.88\%), whilst Asia-Pacific recorded an $82.49 \%$ abandon rate (STATISTA, 2021).

Forrester Research suggests annual losses caused by cart abandonment in the United States is $\$ 18$ trillion (Nichols, 2018) and cost marketer an average of $\$ 2$ to $\$ 4$ trillion per year (Osman, 2021). Shopping cart abandonment also contributes to other problems, such as making products unavailable to a serious buyer and making e-tailers believe that their current pricing and advertising strategies are ineffective. Furthermore, it also twisted website data and analysis (thus resulted in a wrong evaluation of KPIs and marketing campaign performance) due to invalid data caused by this issue. Since shopping cart abandonment is rampant, the purpose of this study is to identify drivers of this behaviour among a leading group of Internet users, which is young people. This study aims to probe into the reason for placing items in the cart, how consumers use their cart, and factors that may hinder the checkout process in seeking an explanation of this behaviour. Findings from this study will help etailers improve the check-out process, create more consumer-friendly sites, select the most effective advertising method to prompt customers to complete the purchasing, and prevent their potential loss caused by shopping cart abandonment by converting online shopping to online buying.

\section{Literature Review}

It has been observed that, when the COVID19 hit the world, people were forced to fully utilize the online portals to shop and fulfil their necessities. As the waves of COVID19 continue, it is surprising to see that shopping cart abandonment still happens during this crucial moment. The term of shopping cart abandonment has been acknowledged since the 1990s, alongside 
the e-commerce boom. Few studies have been conducted to understand why most customers leave an online portal without completing their transaction (Rewick, 2000; Lee and Lee, 2004). Kukar-Kinney and Close (2010) study the reasons behind the incomplete transactions such as promotions, obtaining extra information on products, organizing shopping wish lists, and entertainment. Few significant reasons were highlighted, such as entertainment value, organizational tool, perceived risk, perceived cost and transaction inconvenience.

\section{Organizational Tool}

Consumers may visit various shopping sites to check products as a part of a purposeful ongoing search but without plans to purchase the product immediately. Based on data shared from the Forrester Research survey, about 41 per cent of participants used the online cart as a research tool to gain information (Magill, 2005). Additionally, Forsythe and Shi (2003) suggest that consumers use the Web to search for information more than they do to make purchases. Besides, in the ongoing search case, consumers may use the cart to help them organize items of interest for a potential future purchase, a place to store items, a wish list and a tool to track prices later (Kukar-Kinney and Close, 2010). Therefore, shopping cart abandonment might happen as consumers use it as an organizational tool.

\section{Entertainment Value}

Some studies stated that some experiential-driven shoppers put items in their shopping cart just for entertainment purposes, boredom or enjoyment seeking as it was considered a fun activity (Wolfinbarger and Gilly, 2001; Kukar-Kinney and Close, 2010). These shoppers do not intend to complete the transaction and do not even afford to buy the items; therefore, placing the items in the cart is just an action to fulfil their desire and consider it some escapism (Mathwick, Malhotra and Rigdon, 2001). Besides that, browsing on a website also enables any online shopper to go through a more satisfactory experience (Luo, 2002). These consumers may find the action enjoyable, but these hedonic reasons mean a loss of profit for the sellers. Hence, the cart abandonment might keep affecting the companies' profit.

\section{Perceived Cost}

For the past two years since the pandemic hit us, online shopping has become a preferential option as it can offer many conveniences to society. Among the advantages of e- retailing websites is their ability to sell items at relatively lower prices and provide different discounts to fulfil the shopper's expectations (Maxwell and Maxwell, 2001). This action was aligned with the research conducted by Sondhi (2017), which stated that consumers tend to firstly allocate a budget before shopping, evaluate every product, and then decide after considering the acquisition cost and transaction cost. Besides that, online shoppers are also susceptible to the total cost of all items in the cart, including shipping and handling costs, tax, and other fees that raise the overall cost (Kukar-Kinney and Close, 2010). Nelson, Cohen and Rasmussen (2007) stated that consumers might search for other websites or decide to wait for a sale if they do not satisfy with the total cost. These factors can retain a shopper from completing the transaction.

\section{Perceived Risk}

According to Petersen and Kumar (2009), perceived risk related to future purchases is a valuable element to understand shopping cart abandonment; if consumers feel that the risk is high, they will become more prudent in purchasing the item. Privacy and security of 
personal and financial information are the primary concerns of online shoppers (Myazaki and Fernandez, 2001), especially for the new shoppers that are highly sensitive to the online stores' privacy infringement and the security system (Zhou et al, 2007). Consumers' privacy and security concerns will eventually affect their purchase behaviour and eventually lead to the abandonment of shopping carts.

\section{Transaction Inconvenience}

From logging onto a website to placing items into a virtual cart, many factors can influence shoppers' purchasing decisions, and they might leave the virtual store without buying any item. As stated by Rohm and Swaminathan (2004), one of the reasons for such behaviour is transaction inconvenience. The inconvenience defined by Harrison-Walker (2002) includes complex shopping procedures, long registration forms to be filled up, shipping and handling charges and out of stock products revealed until late in the purchase process, technical glitches and non-availability of alternative methods of payment (other than credit cards). Additionally, excessive time a website may take to load and the transaction process that is too complicated, or the quality of the goods is questionable may lead to frustration (HarrisonWalker, 2002). Rajamma et al (2009) also showed that transaction inconvenience is a significant predictor that causes consumers' ceasing the online shopping process as they expect a fast and website-related convenient process. Hence, we expect that the higher the level of consumers' frustration with transaction inconvenience, the greater the shopping cart abandonment.

\section{Conceptual Framework and Hypotheses Development}

Based on the Theory of Buyer Behaviour by Howard and Sheth's (1969), there are five significant catalysts for the rise of consumer behaviour: high price/overall cost, lack of availability, time pressure, and the consumer's financial status and social influences. This study applies these stimulants to an online context such as perceived cost (high price/overall cost), transaction inconvenience due to the purchasing process and webpage loading time (time pressure), entertainment aspects etc. Furthermore, privacy and security (perceived risk) are introduced since these are pivotal inhibitors to online shopping. After reviewing the relative literature, conceptual framework and formulated hypotheses are presented in Figure 1.

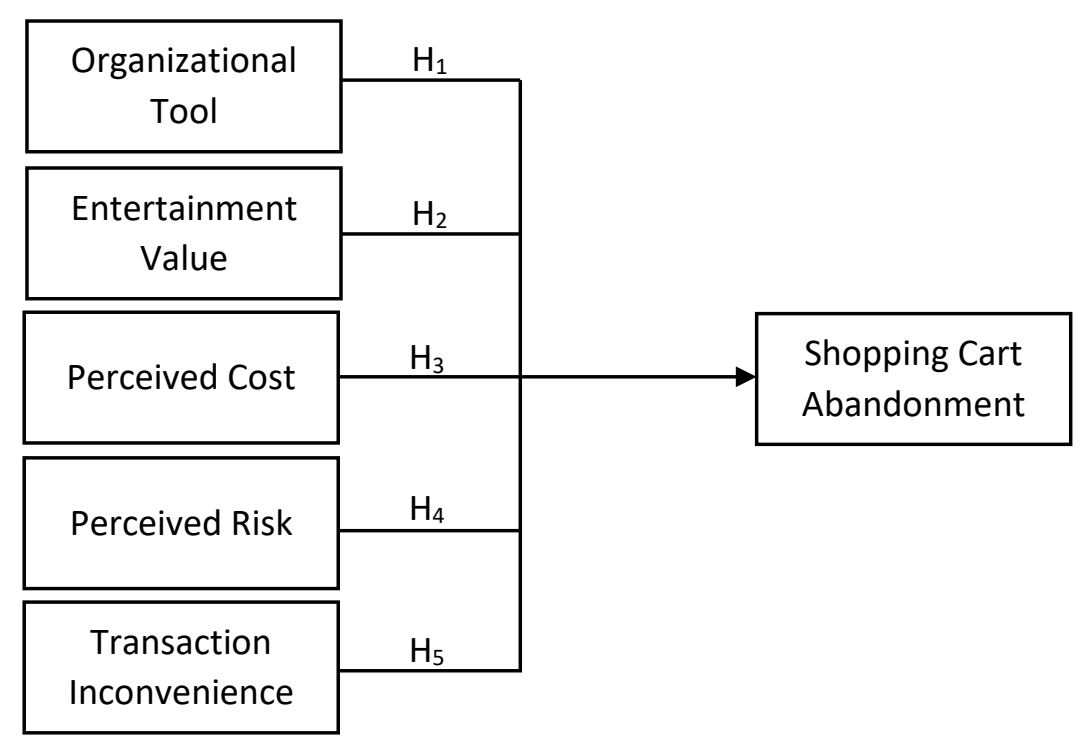

Figure 1: Conceptual Framework of Factors Affecting Shopping Cart Abandonment 
$\mathrm{H}_{1}$ : There is a significant relationship between organizational tool and shopping cart abandonment.

$\mathrm{H}_{2}$ : There is a significant relationship between entertainment value and shopping cart abandonment.

$\mathrm{H}_{3}$ : There is a significant relationship between perceived risk and shopping cart abandonment.

$\mathrm{H}_{4}$ : There is a significant relationship between perceived cost and shopping cart abandonment.

$\mathrm{H}_{5}$ : There is a significant relationship between transaction inconvenience and shopping cart abandonment.

\section{Data and Methodology}

A self-administered online questionnaire was distributed through instant messaging platforms such as WhatsApp and Telegram. The respondents were asked whether they had shopped online at least once during the preceding six months. Only the respondents who had shopped online at least once will be analysed. This survey was conducted from August to September 2021. In the end, 255 completed questionnaires were obtained; nevertheless, we eliminated 3 of them because they did not participate in online shopping during the preceding six months. Since all the questions in the survey were compulsory to answer, no questionnaire was excluded. All the data were statistically tested and analysed on SPSS 22.

The questionnaire consisted of 29 questions in total, and it was divided into seven parts. The first part is to collect demographic information of the respondents (gender, age, level of study, and did they shopped online during the preceding six months). In part two, the questions are about their experience of cart abandonment. Meanwhile, parts three to 7 are about the reasons behind this behaviour: an organisational tool, entertainment value, perceived risk, perceived cost, and transaction inconvenience. The measurement of the survey items using two types of five-point Likert scale. Respondents were asked to choose a Likert scale from 1 (strongly disagree) to 5 (strongly agree) for perceived risk and transaction inconvenience. While in for cart abandonment, perceived cost, organisational tool, and entertainment value, the Likert scale was label as 1 (never) to 5 (always). The questionnaire in this study is developed based on (Erdil, 2018; Kukar-Kinney and Close, 2010).

The focus group of this study is young adults in their $20^{\prime}$ s and 30 's as they accounted for $67.2 \%$ of Internet users in Malaysia (Internet Users Survey, 2020). The younger generation is more familiar with the e-commerce landscape and can grasp information from websites five times faster than the older generations (Kim \& Ammeter, 2008). Furthermore, they prefer to buy or look for products online as it is more convenient and help them to save time and money irrespective of their source of income. They are independent enough to make their own shopping decision (Daud et al., 2016).

\section{Findings and Discussion}

\section{Sample Profile}

The majority of respondents were female (84.5\%), age between $20-29$ years (51.6) and undertaking diploma courses (73.4\%). When they were asked about the frequency of leaving an item in the cart, the majority of the respondent $(67.8 \%)$ indicated minimally $50 \%$ of the 
time they will abandon their cart. Its means they do not complete the check-out at least once every two times of their visit to the shopping portal/website.

Table 1: Demographic Information of Respondents

\begin{tabular}{|c|c|c|c|}
\hline Demographic information & & Frequency & $\%$ \\
\hline \multirow[t]{4}{*}{ Gender } & Male & 39 & 15.5 \\
\hline & Female & 213 & 84.5 \\
\hline & & 252 & 100 \\
\hline & $18-19$ years & 119 & 47.2 \\
\hline \multirow[t]{3}{*}{ Age } & $20-29$ years & 130 & 51.6 \\
\hline & $30-39$ years & 3 & 1.2 \\
\hline & & 252 & 100 \\
\hline \multirow{5}{*}{ Level of study } & Diploma & 185 & 73.4 \\
\hline & Degree & 67 & 26.6 \\
\hline & & 252 & 100 \\
\hline & $0 \%$ & 10 & 4 \\
\hline & $1-9 \%$ & 7 & 2.8 \\
\hline \multirow{10}{*}{$\begin{array}{l}\text { Frequency of } \\
\text { abandonment in } \%\end{array}$} & $10-19 \%$ & 12 & 4.8 \\
\hline & $20-29 \%$ & 20 & 7.9 \\
\hline & $30-39 \%$ & 17 & 6.7 \\
\hline & $40-49 \%$ & 15 & 6 \\
\hline & $50-59 \%$ & 47 & 18.7 \\
\hline & $60-69 \%$ & 31 & 12.3 \\
\hline & $70-79 \%$ & 33 & 13 \\
\hline & $80-89 \%$ & 30 & 11.9 \\
\hline & $90-100 \%$ & 30 & 11.9 \\
\hline & & 252 & 100 \\
\hline
\end{tabular}

\section{Descriptive Analysis}

Table 2 shown the means of six variables in this study. Organizational tool represented the highest mean (4.21 out of 5) among all variables. It indicates the majority of the respondent often use the shopping cart as a tool to organize items of interest for a potential future purchase and research purpose. Meanwhile, the lowest mean (2.63 out of 5) is related to the variable of entertainment value. This result shows the majority of the respondent rarely use the shopping cart as an entertainment tool. It also documented that most of the respondents agree that privacy and security are among their primary concerns when visiting online shopping websites. 
Table 2: Descriptive Statistics for Variable

\begin{tabular}{llll}
\hline Variable & No. of questions & Mean & $\begin{array}{l}\text { Standard } \\
\text { Deviation }\end{array}$ \\
\hline Organizational tool & 3 & 4.21 & 0.87 \\
Entertainment value & 2 & 2.63 & 1.28 \\
Perceived risk & 3 & 4.06 & 0.71 \\
Perceived cost & 6 & 3.63 & 0.60 \\
Transaction inconvenience & 5 & 3.65 & 0.72 \\
Shopping cart abandonment & 4 & 3.60 & 0.87 \\
\hline
\end{tabular}

\section{Reliability Analysis}

Cronbach's alpha measures internal consistency to see how closely related a set of items are as a group. The closest value of Cronbach's alpha to 1 shows the better the measuring instrument (Sekaran, 2003). According to Cortina (1993), any coefficient above 0.70 is acceptable, and 0.80 or greater is preferred. Thus, Cronbach's Alpha value in Table 3 illustrates that this instrument is reliable to measure all the variables.

Table 3: Cronbach's Alpha Result

\begin{tabular}{lll}
\hline Variable & No.of questions & $\begin{array}{l}\text { Cronbach's } \\
\text { Value }\end{array}$ \\
\hline Organizational tool & 3 & 0.815 \\
Entertainment value & 2 & 0.880 \\
Perceived risk & 3 & 0.731 \\
Perceived cost & 6 & 0.700 \\
Transaction inconvenience & 5 & 0.833 \\
Shopping cart abandonment & 4 & 0.819 \\
\hline
\end{tabular}

\section{Regression Analysis}

As revealed in Table 4, 58.1\% of shopping cart abandonment can be linked with the organizational tool, entertainment value, perceived risk, perceived cost, transaction inconvenience $(\mathrm{R}=0.581)$. However, only $33.8 \%$ variation in shopping cart abandonment can be justified by organizational tool, entertainment value, perceived risk, perceived cost, transaction inconvenience ( $\mathrm{R}$-square $=0.338$ ).

Table 4: Model Summary

\begin{tabular}{lllll}
\hline Model & $\mathbf{R}$ & R Square & Adjusted R Square & $\begin{array}{l}\text { Std. Error of the } \\
\text { Estimate }\end{array}$ \\
\hline 1 & $0.581^{\mathrm{a}}$ & 0.338 & 0.324 & 0.71580 \\
\hline
\end{tabular}

Table 5 reveal this model (that linking organizational tool, entertainment value, perceived risk, perceived cost, transaction inconvenience with shopping cart abandonment) is fitted to established the significant linear relationship as F-statistics created ( $f=25.098$ ) is significant at 1 percent level (sig. $f<0.01$ ) with 5 and 246 degrees of freedom. 
INTERNATIONAL JOURNAL OF ACADEMIC RESEARCH IN BUSINESS AND SOCIAL SCIENCES Vol. 11, No. 10, 2021, E-ISSN: 2222-6990 @ 2021 HRMARS

Table 5: ANOVA

\begin{tabular}{llllllll}
\hline \multirow{2}{*}{ Model } & & $\begin{array}{l}\text { Sum } \\
\text { Squares }\end{array}$ & of & df & Mean Square & F & Sig. \\
\hline \multirow{3}{*}{1} & Regression & 64.297 & 5 & 12.859 & 25.098 & $.000^{\mathrm{b}}$ \\
& Residual & 126.042 & 246 & .512 & & \\
& Total & 190.339 & 251 & & & \\
\hline
\end{tabular}

Based on Table 6, organizational tool, entertainment value and perceived cost are significantly related to shopping cart abandonment; meanwhile, the other two factors (perceived risk and transaction inconvenience) have no significant relationship with shopping cart abandonment. Organizational tools $(\beta 1=0.437, t=7.397)$, entertainment value $(\beta 1=$ $0.120, t=2.070)$ and perceived cost $(\beta 1=0.181, t=3.217)$ significantly related to the shopping cart abandonment at $\mathrm{p}<0.05$. For that reason, $\mathrm{H} 1, \mathrm{H} 2$ and $\mathrm{H} 3$ are accepted whereas $\mathrm{H} 4$ and $\mathrm{H} 5$ are not supported.

Table 6: Coefficients

\begin{tabular}{lllllll}
\hline \multirow{2}{*}{ Model } & \multicolumn{2}{l}{$\begin{array}{l}\text { Unstandardized } \\
\text { Coefficients }\end{array}$} & \multicolumn{2}{l}{$\begin{array}{l}\text { Standardized } \\
\text { Coefficients }\end{array}$} & t & \multirow{2}{*}{ Sig. } \\
\cline { 2 - 5 } & B & Std. Error & Beta & & \\
\hline Constant & 0.918 & 0.413 & & 2.224 & 0.027 \\
$\quad$ Organizational tool & 0.440 & 0.059 & 0.437 & 7.397 & 0.000 \\
& Entertainment value & 0.082 & 0.040 & 0.120 & 2.070 & 0.040 \\
$1 \quad$ Perceived risk & -0.019 & 0.067 & -0.016 & -.288 & 0.773 \\
& Perceived cost & 0.261 & 0.081 & 0.181 & 3.217 & 0.001 \\
& Transaction inconvenience & -0.071 & 0.068 & -0.059 & -1.057 & 0.291 \\
\hline
\end{tabular}




\section{Correlation Analysis}

Table 7: Correlation Table

\begin{tabular}{|c|c|c|c|c|c|c|c|}
\hline & & $\begin{array}{l}\text { Organiza } \\
\text { tional } \\
\text { tool }\end{array}$ & $\begin{array}{l}\text { Entertai } \\
\text { nment }\end{array}$ & Risk & Cost & $\begin{array}{l}\text { Transacti } \\
\text { on } \\
\text { inconven } \\
\text { ience }\end{array}$ & Abandon \\
\hline \multirow{4}{*}{$\begin{array}{l}\text { Organizati } \\
\text { onal } \\
\text { tool }\end{array}$} & Pearson & 1 & & & & & \\
\hline & Correlation & & & & & & \\
\hline & Sig. (2-tailed) & & & & & & \\
\hline & $\mathrm{N}$ & 252 & & & & & \\
\hline \multirow{4}{*}{$\begin{array}{l}\text { Entertain } \\
\text { ment }\end{array}$} & Pearson & $.416 * *$ & 1 & & & & \\
\hline & Correlation & & & & & & \\
\hline & Sig. (2-tailed) & .000 & & & & & \\
\hline & $\mathrm{N}$ & 252 & 252 & & & & \\
\hline \multirow{4}{*}{ Risk } & Pearson & -.017 & .010 & 1 & & & \\
\hline & Correlation & & & & & & \\
\hline & Sig. (2-tailed) & .790 & .871 & & & & \\
\hline & $\mathrm{N}$ & 252 & 252 & 252 & & & \\
\hline \multirow{4}{*}{ Cost } & Pearson & $.336^{* *}$ & $.269 * *$ & .044 & 1 & & \\
\hline & Correlation & & & & & & \\
\hline & Sig. (2-tailed) & .000 & .000 & .488 & & & \\
\hline & $\mathrm{N}$ & 252 & 252 & 252 & 252 & & \\
\hline \multirow{4}{*}{$\begin{array}{l}\text { Transactio } \\
\mathrm{n} \\
\text { inconveni } \\
\text { ence }\end{array}$} & Pearson & $.134^{*}$ & $.172 * *$ & $.290 * *$ & $.195 * *$ & 1 & \\
\hline & Correlation & & & & & & \\
\hline & Sig. (2-tailed) & .033 & .006 & .000 & .002 & & \\
\hline & $\mathrm{N}$ & 252 & 252 & 252 & 252 & 252 & \\
\hline \multirow{4}{*}{ Abandon } & Pearson & $.540 * *$ & $.341 * *$ & -.031 & $.348 * *$ & .051 & 1 \\
\hline & Correlation & & & & & & \\
\hline & Sig. (2-tailed) & .000 & .000 & .624 & .000 & .419 & \\
\hline & $\mathrm{N}$ & 252 & 252 & 252 & 252 & 252 & 252 \\
\hline
\end{tabular}

**. Correlation is significant at the 0.01 level (2-tailed).

*. Correlation is significant at the 0.05 level (2-tailed).

As revealed in Table 7, organizational tool, entertainment value, and perceived cost positively correlate with shopping cart abandonment at $p<0.01$. This result could be interpreted as follow. Firstly, the more respondents use the cart as an organizational tool, the more likely they will abandon the item. Second, if the respondent believes the cost is high, they will not proceed with the checkout. Lastly, the more respondents use the cart as entertainment (place items in the cart for fun or when they are bored), the more chance of abandonment of the shopping cart.

\section{Conclusion}

Due to the outbreak of COVID-19, the implementation of Movement Control Order (MCO) and closure of business activities has led to the growth in online buying activities. The rise in online activities has affected both the buying and abandonment of the items in the online portal. We conducted this research to understand the customers' behaviour, and the 
evidence suggests that all the questions designed are reliable to measure each variable. The result confirming Kukar-Kinney and Close (2010) as the majority of the respondents often use the shopping cart as a tool to organize items of interest. It also documented the high cart abandonment ratio at least once every two times of their visit. Although the study involved young adults, especially students as respondents, the result surprisingly shows that the majority of the respondent rarely use the shopping cart as entertainment value.

Besides, the finding in the regression analysis found that only organizational tools, entertainment value and perceived cost are significantly related to shopping cart abandonment. Similarly, the further test in correlation analysis also shows that organizational tool, entertainment value and perceived cost have a positively significant relationship with shopping cart abandonment at $p<0.01$. This result could be interpreted as the more respondents use the cart as an organizational and entertainment tool and are highly sensitive about the cost, the more likely they will abandon the item. Our findings appear to be well confirmed with the study by Wu et al (2014) that stated online transaction cost is known to have a significant effect on the online shopping process. As expected, it also confirmed the study by Kukar-Kinney and Close (2010) that find consumers used shopping carts for research purposes and to seek enjoyment.

This paper indicates that shopping cart abandonment is closely connected to the respondents' opinion on the online activities. It is mainly about customers' expectations on the online portal, and their dissatisfaction might resulting in the abandonment of their shopping cart. Therefore, this situation needs to be explored and tested further with different respondents since Kuhlmeier and Knight (2015) also found that consumers from other countries have varying levels of perceived risk. Additionally, future researches also can include the mediating factors that might influence the respondents' final decision. Doing that would create a broader view of the customers' behaviour in shopping cart abandonment and help the relevant website/portal improve their services.

\section{References}

Bhatti, A., Akram, H., Basit, H. M., Khan, A. U., Raza, S. M., \& Naqvi, M. B. (2020). E-commerce trends during COVID-19 Pandemic. International Journal of Future Generation Communication and Networking, 13(2), 1449-1452.

Coppola, J., \& Sousa, K. (2008). Characteristics affecting the abandonment of e-commerce shopping carts - a pilot study. Northeast Decision Sciences Institute Proceedings, 384389.

Cortina, J. M. (1993). What is coefficient alpha? An examination of theory and applications. Journal of applied psychology, 78(1), 98.

Daud, N. M., Mohd, N. R. N., Shamsudin, N. S., Zaidan, N. K., \& Mohamed, I. S. (2016). Facors that influence student's behavior on online shopping in Malaysia. PONTE International Journal of Science and Research, 72(4).

Department of Statistics, Malaysia. (2021). Income of E-Commerce Transactions Surged 30.0 per cent in The First Quarter 2021. https://www.dosm.gov.my/v1/index.php?r=column/cthemeByCat\&cat=489\&bul_id=c 1FiaHRCQnIRdkxzUUFkNFJncWtEQT09\&menu_id=b0pIV1E3RW40VWRTUkZocEhyZ1pL UT09. 
Erdil, M. (2018). Factors affecting shopping cart abandonment: pre-decisional conflict as a mediator. Journal of Management Marketing and Logistics, 5(2), 140-152.

Forsythe, S. M., \& Shi, B. (2003). Consumer patronage and risk perceptions in Internet shopping. Journal of Business research, 56(11), 867-875.

Gurley, J. W. (2000): The one Internet metric that really matters. Fortune 2000;141: 392[March 6]

Harrison-Walker, J. L. (2002). If you build it, will they come? Barriers to international emarketing. Journal of Marketing Theory and Practice, 10, 12-21.

Howard, J. A., \& Sheth, J. N. (1969). The theory of buyer behavior. New York, 63.

Kee, D. M. H., Nasser, S. N. A., Sany, N. S. M., Azhar, T. I., Roslan, Z. H., \& Amli, N. A. (2021). The Strategy, Impact, and Challenges Faced by Pos Malaysia Berhad during the COVID19 Crisis. Journal of the Community Development in Asia (JCDA), 4(2), 13-25.

Kim, D., Ammeter, A. P. (2008). Examining shifts in online purchasing behavior: decoding the net generation. Academy of Information and Management Sciences Proceedings, Vol. 12, No. 1

Kuhlmeier, D., \& Knight, G. (2005). Antecedents to internet-based purchasing: a multinational study. International Marketing Review.

Kukar-Kinney, M., \& Close, A. G. (2010). The determinants of consumers' online shopping cart abandonment. Journal of the Academy of Marketing Science, 38(2), 240-250.

Lee, B. K., \& Lee, W. N. (2004). The effect of information over-load on consumer choice quality in an on-line environment. Psychology and Marketing, 21, 159-183.

Luo, X. (2002). Uses and gratifications theory and e-consumer behaviors: a structural equation modeling study. Journal of Interactive Advertising, 2(2), 34-41.

Magill, K. (2005). Building a better shopping cart. Multichannel Merchant, 1(8), 18-19.

Malaysian Communications and Multimedia Commission. (2020). Internet Users Survey 2020, https://www.mcmc.gov.my/skmmgovmy/media/General/pdf/IUS-2020-Report.pdf.

Retrieved on 20 September 2021.

Mathwick, C., Malhotra, N., \& Rigdon, E. (2001). Experiential value: conceptualization, measurement and application in the catalog and internet shopping environment. Journal of Retailing, 77(1), 39-56.

Maxwell, S., \& Maxwell, N. (2001). Channel reference prices: the potentially damaging effects of napster. Proceedings of the 2001 Fordham University Behavioral Pricing Conference, 32

Myazaki, A. D., \& Fernandez, A. (2001). Consumer perceptions of privacy and security risks for online shopping. Journal of Consumer Affairs, 35, 27-44.

Nelson, R. A., Cohen, R., \& Rasmussen, F. R. (2007). An analysis of pricing strategy and price dispersion on the internet. Eastern Economic Journal, 33(1), 95-110.

Nichols, R. (2018) Understanding Shopping Cart Abandonment, https://www.abtasty.com/blog/understanding-shopping-cart-abandonment/. Retrieved on 20 September 2021.

Osman, M. (2021), How to Decrease Shopping Cart Abandonment on Your Ecommerce Site, https://kinsta.com/blog/shopping-cart-abandonment/. Retrieved on 20 September 2021.

Petersen, J. A., \& Kumar, V. (2009). Are product returns a necessary evil? Antecedents and consequences. Journal of Marketing, 73, 35-51. 
Rajamma, R., Paswan, A., \& Hossain, M. (2009). Why do shoppers abandon shopping carts? Perceived waiting time, risk, and transaction inconvenience. Journal of Product \& Brand Management, 18, 188-197.

Rewick, J. (2000). Clinching the holiday e-sale: some $65 \%$ of online shopper's bolt at the checkout point; e-tailers try to keep them. Wall Street Journal, B1. October 9.

Rohm, A. J., \& Swaminathan, V. (2004). A typology of online shoppers based on shopping motivations. Journal of business research, 57(7), 748-757.

Sekaran, U. (2003). Research Methods for Business: A Skill Building Approarch Fourth Edition. New York, NY; John Wiley and Sons Inc.

Sondhi, N. (2017). Segmenting \& profiling the deflecting customer: understanding shopping cart abandonment. Procedia Computer Science, 122, 392-399.

Statista. (2021). Online shopping cart abandonment rate in 2020, by region, https://www.statista.com/statistics/546885/cart-abandonment-rate-region/. Retrieved on 20 September, 2021.

Wolfinbarger, M., \& Gilly, M. C. (2001). Shopping online for freedom, control, and fun. California management review, 43(2), 34-55.

Wu, L. Y., Chen, K. Y., Chen, P. Y., \& Cheng, S. L. (2014). Perceived value, transaction cost, and repurchase-intention in online shopping: A relational exchange perspective. Journal of business research, 67(1), 2768-2776.

Zhou, L., Dai, L., \& Zhang, D. (2007). Online shopping acceptance model-a critical survey of consumers factors in online shopping. Journal of Electronic Commerce Research, 8(1), 41-62. 